\title{
АНАЛИЗ СПОСОБОВ РАСЧЕТА ФАЗОВЫХ ПРОНИЦАЕМОСТЕЙ ПО ВОДЕ И УГЛЕВОДОРОДАМ И СОПОСТАВЛЕНИЕ ИХ С ЭКСПЕРИМЕНТАЛЬНЫМИ ДАННЫМИ \\ Дорогиничкая Л.М.
}

(ООО "Сиб́петролаб", ООО Научно-исспедовательский иентр "Сибгеонафт»)

Аннотащия. Относительные фазовые проницаемости (ОФП) по пластовой воде и углеводородам характеризуют движение флюидов в продуктивном пласте в процессе добычи, обусловливают обводнение притока в скважину и подлежат обязательному изучению. Недостатки и дороговизна скважинньт и экспериментальньх лабораторных способов исследования побуждает искать более экспрессные и недорогие расчетные способы оценки ОФП. Однако данные сравнения результатов расчета с экспериментом практически отсулствуют. Доклад посвящен этому вопросу. Делается вывод об эффективности способа расчета фазовьхх проницаемостей по формулам Пирсона, основанных на определенной аналогии законов Ома и Дарси-Нугтинга.

В настоящее время хорошо известны способы расчета ОФЗ и функций обводнения гритока на базе кривых капиллярного давления, характеризующих распределение эффективных поровых каналов пористой среды по размерам. В формулах Бурдайна несоответствие трубчатой (капиллярной) модели породы c реальной учитывается с помощью литологических констант [1]. Позднее были предложены геометрически более совершенные модели хаотического порового пространства пород-коллекторов с использованием теории перколяция [2, 3]. Однако и они не учитывают молекулярного взаимодействия поровых флюидов с твердой фазой, значительно возрастающего с увеличением в породе количесгва активных к воде глинистъх пастиц, пелитизированных полевых шпатов и гидратированных слюд. Хорошо известно, что в силу дипольного строения молекул воды ее структура на гранище с твердой фазой упорядочена с образованием двойньх электрических слоев. Адсорбированная вода отличается от свободной по физическим свойствам и минерализация. Большой объем расчетов, выполненньгх для разньгх типов коллекторов, показал, что экспериментальные ОФЗ хорошо согласуются с рассчитанными на базе хаотической перколяционной модели пород-коллекторов, если количество воды, испытывающей влияние твердой фазы не превыпшает $\sim 40 \%$. Для высокодисперснбх глинистых коллекторов совпадения не достигается, рис.1. Технология расчетов подробно изложена нами в работе [4]. Следует отметить, что несмотря на относительную простоту используемьх уравнений есть определенные трудности из-за выбора пределов интегрирования и способа нормировки.

Взаимодействие пластовой воды с твердой фазой заложено в экспериментальных связях электрического параметра насыщения с водонасыщенностью пород. Поэтому предложенные С.Д. Пирсоном уравнения для расчета фазовых проницаемостей на базе

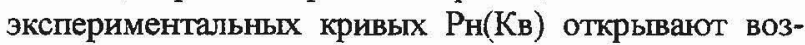
можность учета влияния адсорбционной пленочной воды на движкение пластовой воды в поровом пространстве [5].

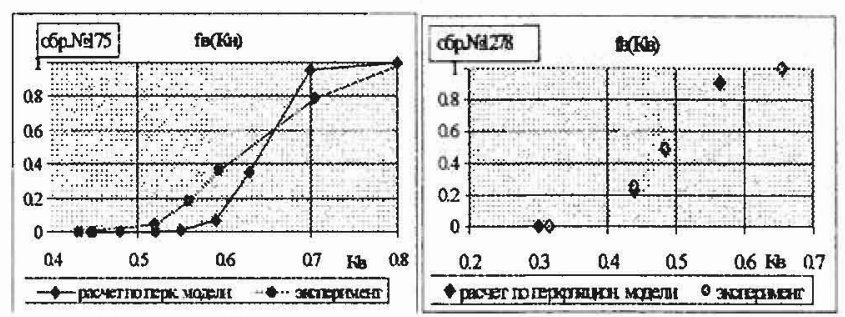

Рис.1. Функции обводнения притока для коллекторов с разньм количеством прочно связанной воды ( №1278- Кп=0,23; Кпр=206млд; Кво $=0,3$; №175- Кп=0,156; Кпр=10млд; Кво $=0,44)$.

Количество аномальной прочно связанной воды Квс определено как предельное на капиллярных давлениях более 20 атм и коррелируется с количеством остаточной Кво. Кроме уравнений Пирсона взаимодействие флюидов с твердой фазой учитывают также июженерные формулы Национального Нефияного Совета США, полученные на базе статистического обобщения экспериментальных данных [6], рис. 2.

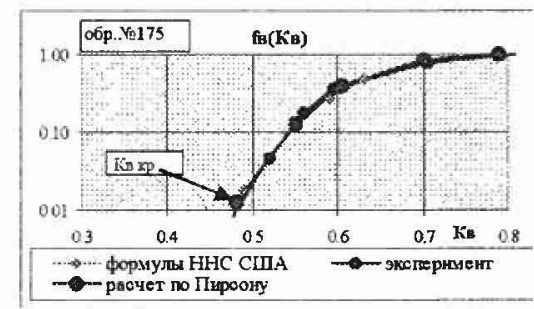

Рнс.2 Функиия обводнения притока для коллектора с Кп=0,156: Кпр=10млд; Кво $=0,444$.

\section{ЛИТЕРАТУРА}

Дж.Аиккс. Физика нефтяного пласта. - М.:Гостоптехиздат, 1962. C. 59-197.

Мальшаков А.В. Ефимов В.А. Проницаемость и перко.яяпионные свойства порового пространства осадочных горных пород // Инженерный журнал. - 1991.-Т. 61, №4.- С. 635-640.

Багринцева К.И. Условия формкрования и свойства карбонатных гол.екторов нефти и газа. - М., 1999. - С. 61-69.

Дорогиницкая Л.М., Дергачева Т.Н., Анашкин А.Р. и др. Количественная оценка добынњых характеристик коллекторов нефти и газа по петрофизическим данным и материалам ГИС. Томск: STT, 2007.

Пнрсон С.Д. Учение о нефтяном пласте. М.: Госттоптехиздат,1961. С. 96-109.

Дон Уолкотт. Разработка и управление месторождениями при заводнении. М.: ЮКОС, 2001. 